\title{
КОНЦЕПТУАЛЬНІ ЗАСАДИ ПРОФЕСІЙНОЇ ПІДГОТОВКИ МАЙБУТНІХ ФАХІВЦІВ ЗАЛІЗНИЧНОГО ТРАНСПОРТУ В УМОВАХ НЕПЕРЕРВНОЇ ОСВІТИ
}

\author{
Маланюк Н. М.
}

\section{ВСТУП}

Професійна освіта сьогодення зазнає глобальних впливів євроінтеграційних процесів, стрімкого розвитку науки й техніки, впровадження інформаційних технологій в усі ланки життя та діяльності людини. Новітнього освітньою парадигмою стає компетентнісна, яка прийшла на зміну знаннєвій: знання не статичною системою, а динамічною. У світлі мінливості інформаційного потоку, стрімкого оновлення та доповнення знань, науково-технічного прогресу знання $\epsilon$ не кінцевим результатом здобутої освіти (продуктом), а лише підгрунтям для формування та розвитку професійних компетентностей майбутніх фахівців. Світова мобільність ринку праці висуває єдині вимоги до всіх кандидатів на здобуття певної посади - володіти низкою компетентностей, визначальними якостями характеру, мати сформований ціннісно-мотиваційний орієнтир тощо.

Через імплементацію України у європейський освітній простір не повинно бути занедбано всі позитивні здобутки вітчизняної педагогічної науки. Професійна освіта потребує оновлення та модернізації освітніх стандартів, покращення якісних показників як освітнього процесу, так і кінцевого результату. Для цього необхідно враховувати не лише досвід європейських колег, а й також власний, десятиліттями набутий практичний досвід, зберігаючи національну самобутність.

Професійна підготовка фахівців залізничного транспорту на сучасному етапі має за мету підготовку конкурентоспроможних фахівців у галузі транспортної інфраструктури, які мають сформовану систему національних, загальних, культурних цінностей, володіють стійкою позицією стосовно важливості «навчання протягом життя»; гармонійне поєднання професійної підготовки з усебічним розвитком кожного студента, виходячи iз наявних задатків i здібностей; формування низки загальних $\mathrm{i}$ спеціальних компетентностей у майбутніх фахівців залізничного транспорту. 
Вітчизняні та європейські вчені перебувають у постійному пошуку оптимального поєднання змісту, форм, методів, технологій навчання на всіх рівнях неперервної освіти 3 метою забезпечення всебічного та гармонійного розвитку кожного студента у процесі здобування професійної освіти.

\section{1. Особистісно-оріснтований підхід у закладах професійної освіти (ЗПО)}

Впровадження особистісно-орієнтованого підходу в освітній процес у ЗПО повинно відбуватися цілісно, системно: в центрі освітнього процесу - особистість студента, яка володіє низкою задатків i здібностей. Завдання ЗПО - допомогти кожному студенту розкрити свій потенціал, виходячи 3 наявних здібностей, розвиваючи їх i формуючи на цій основі якості, потрібні для успішного виконання професійних обов'язків. Результатом навчання в закладах професійної освіти різних рівнів акредитації має стати не набір розрізненої інформації з усеможливих галузей знань, а сформована особистість, готова до якісного здійснення професійної діяльності, здатна до самовдосконалення та підвищення свого професійного рівня.

Доволі часто заявлений курс на особистісно-орієнтоване навчання в закладі освіти зводиться лише до того, що викладачі та дирекція погоджуються 3 ідеями гуманістичного підходу в психології, який лежить в основі особистісно-орієнтованого навчання, хоча повинні будувати свою діяльність, враховуючи принципи цього підходу. Гуманістична психологія інтенсивно розвивається від середини XX ст. А. Маслоу стверджував, що особистість $є$ найбільшою цінністю, яка потребує задоволення низки потреб, серед яких - потреба в самореалізації ${ }^{1}$. Розвиваючи ідеї А. Маслоу, психолог К. Роджерс наголошував, що тільки особистість, яка працює над собою, розвиває свої здібності та задатки, буде автором цінностей у будь-якій діяльності $^{2}$. Гуманізація освіти нині прописана в основних законах (Законі «Про освіту», «Про вищу освіту», Державній національній програмі «Освіта» («Україна XXI століття») тощо). Заклади професійної освіти різних рівнів акредитації покликані допомогти студенту зрозуміти сутність обраної професії та вимоги до іiі виконання; мету, зміст, функціональні обов'язки; індивідуальні

\footnotetext{
${ }^{1}$ Abraham H. Maslow. Motivation and Personality. New York : Harper \& Row, 1970; Санкт-Петербург : Евразия, 1999.

2 Роджерс К. Становление личности: взгляд на психотерапию. URL: http://psylib.org.ua/books/roger01/index.htm. 
стратегії у професійній діяльності; професійну майстерність; можливість творчості у майбутній діяльності ${ }^{3}$.

Академік Н. Ничкало визначає для розвитку професійної освіти на сучасному етапі такі пріоритети: інтелектуалізацію; особистісноорієнтоване навчання; формування ринку освітніх послуг; модернізацію всіх видів забезпечення професійної освіти; міжнародну співпрацю ${ }^{4}$.

Ми вважаємо, що особистісно-орієнтований підхід в освітній діяльності як у закладах загальноосвітніх, так і вищих (у т. ч. фахових професійних) має стати основним підходом, оскільки саме він дозволяє сформувати кожну особистість, враховуючи іï потенціал, котра буде здатною до успішного виконання професійних обов'язків, а також володітиме стійкими моральними якостями та ціннісними орієнтирами. Нині налічується велика кількість різноманітних освітніх підходів, які, на нашу думку, повинні «сприяти» реалізації ідей особистісноорієнтованого навчання залежно від конкретних освітніх цілей.

Ціль особистісно-орієнтованого навчання нині - «розгледіти» якісні властивості кожного студента; сприяти формуванню позитивної мотивації до навчання в кожного студента; навчити студентів механізмів реалізації адаптації, самоорганізації, саморозвитку, самозахисту тощо ${ }^{5}$.

Студенти I курсу коледжів (зазвичай 15-16-річні особистості), які не розкрили в собі творчий потенціал або розкрили не до кінця, потребують допомоги в організації освітньої діяльності (плану, самостійного аспекту та ін.), пізнання майбутньої професії та своїх можливостей у ній. Вони також відрізняються рівнем навчальних досягнень у різних навчальних дисциплінах, сформованістю чи відсутністю позитивної мотивації до освітнього процесу. Тому неможливо організовувати навчання, не враховуючи індивідуальних особливостей кожного учасника освітнього процесу. Це можливо лише із впровадженням особистісно-орієнтованого підходу в діяльність закладів професійної освіти.

Науковець Т. Шамова вказує на такі ключові позиції особистісноорієнтованого навчання:

\footnotetext{
${ }^{3}$ Авдеева Н. Ключевые компетенции - новая парадигма результата образования. Педагогика. 2003. № 5. С. 34.

${ }^{4}$ Профтехосвіта України: ХХ століття / за ред. Н.Г. Ничкало. Київ : АртЕк, 2004. C. 523; Проектування процесу професійного навчання у закладах профтехосвіти : монографія / за ред. Н.Г. Ничкало. Київ - Хмельницький : ХНУ, 2010. С. 7.

${ }^{5}$ Горбатюк О.В. Особистісно орієнтований підхід до навчання в ВНЗ у сучасних умовах. Збірник наукових пращь Кам'янещь-Подільського начіонального університету ім. Івана Огієнка. Серія: Педагогіка. 2014. Вип. 20. С. 252-253.
} 
1. Особистісно-орієнтоване навчання має сприяти розвитку та саморозвитку кожної особистості.

2. Особистісно-орієнтоване навчання покликане допомогти кожному студенту самореалізуватися в різних видах діяльності, базуючись на їхніх задатках і ціннісних орієнтирах.

3. Студент повинен мати вільний вибір предметного матеріалу та засобів реалізації освітнього процесу.

4. Мета освіти сьогодення - формування різних груп компетентностей і розвиток здібностей у кожного студента.

5. Особистісно-орієнтоване навчання як база для освіченості (самоутвердження, саморозвиток, самовираження майбутнього фахівця $)^{6}$.

Для того, щоб особистісно-орієнтований підхід був на практиці реалізований у закладі освіти, необхідно, щоб студент проявляв активність і бажання розвиватися та самовдосконалюватися, а також щоб викладач був готовим (теоретично та практично) до впровадження принципів особистісно-орієнтованого навчання. Особистість студента як суб'єкта навчально-пізнавальної діяльності, оскільки в нього є певна життєва позиція, потреби, мрії, прагнення, ідеали, ставлення до знань тощо, відіграє важливу роль в організації особистісно-орієнтованого підходу. Наявність цих аспектів сприяє (або не сприяє) підвищенню позитивної мотивації до освітньої діяльності. 3 іншого боку, особистість викладача - організатора та керівника освітнім процесом із наявним чи відсутнім прагненням бачити в кожному студентові особистість, яка $\epsilon$ неповторною й однаково цінною, допомогти кожному студенту розвивати свої кращі якості, формувати ціннісні орієнтири та різні групи компетентностей (компетенцій).

Дослідник І. Якиманська стверджує, що «навчити можна будь-кого та будь-чого» ${ }^{7}$. Авторка наголошує: навчатися для освіченості кожен повинен сам - від планування діяльності до формування ставлення до неї, враховуючи особисті потреби, здібності, інтереси. Із цього випливає, що для успішної реалізації особистісно-орієнтованого підходу в освітній процес у закладах професійної освіти необхідно, щоб відбувалася співпраця студента та викладача. Студент як будівник свого життя, майбутнього, себе як професіонала, як особистості, 3 одного боку, з іншого - викладач як керівник, наставник, спрямовувач i коригувальник навчально-пізнавальної діяльності студента. Відмінність

${ }^{6}$ Шамова Т.И. Управление образовательным процессом в адаптивной школе. Москва : Центр «Педагогический поиск», 2001. 384 с.

7 Якиманская И.С. Технология личностно-ориентированного обучения в современной школе. Москва : Сентябрь, 2000. С. 26. 
між когнітивно-орієнтованим навчанням та особистісно-орієнтованим навчанням полягає у «формулі навчання»: в першому випадку - вчити всіх однаково, у другому - вчити кожного по-особливому, враховуючи індивідуальні особливості, здібності, задатки, інтереси та потреби кожного.

Основним завданням викладача за особистісно-орієнтованого підходу є не передача (трансляція чи ретрансляція) знань, а сприяння утвердженню особистості, формування іiі як фахівця, громадянина 3 чіткою цілісною системою морально-ціннісних орієнтирів, прагненням до самовдосконалення, саморозвитку.

Реалізація ідей і принципів особистісно-орієнтованого навчання при підготовці майбутніх фахівців залізничного транспорту відбувається так:

1. Діагностика мотивації до освітньої діяльності (психолог, куратор, викладачі).

2. Пошук факторів, які сприятимуть підвищенню мотивації до навчально-пізнавальної діяльності.

3. Формування переліку якостей, необхідних для якісного виконання професійних обов'язків.

4. Організація освітньої діяльності при вивченні як загальних, так i спеціальних дисциплін 3 урахуванням індивідуальних особливостей, здібностей і потреб кожного студента. Цей момент досягається шляхом впровадження індивідуальних i рівневих завдань, подачі нового матеріалу 3 використанням інноваційних методик, інформаційних технологій із метою активації у студентів різних видів сприйняття (слуху, зору, дотику тощо). Причому за студентом зберігається право вибору рівня завдань, форми подачі інформації, джерела пошуку інформації.

5. Використання інноваційних педагогічних технологій сприяє розвитку творчого потенціалу кожної особистості (можливості прояву задатків і здібностей).

6. Оцінка досягнень кожного студента не порівняно 3 іншими, а порівняно із собою, щоб оцінити динаміку, еволюцію особистісного розвитку.

7. Побудова індивідуальних траєкторій розвитку та саморозвитку кожного студента.

8. Формування ціннісних орієнтирів, серед яких - цінність знань, прагнення до вдосконалення та саморозвитку, підвищення свого професійного рівня, життєвої позиції - навчання протягом життя.

Особистісно-орієнтований підхід не може бути вповні реалізований одним викладачем: для цього потрібна співпраця викладачіводнодумців, керівників закладу освіти, які спільно напрацьовують 
стратегії та плани втілення в життя ідей особистісно-орієнтованого підходу. Лише за цієї умови можна очікувати високих результатів у формуванні та розвитку кожної окремо взятої особистості майбутнього фахівця залізничного транспорту.

\section{2. Діяльнісний підхід у закладах професійної освіти}

Особистість перебуває у центрі освітнього процесу, проте вона не перебуває в деякому «нерухомому» стані. Для розвитку особистості вона повинна бути включена в різнопланову діяльність: освітню, пізнавальну, професійну, творчу тощо. Тому важливого значення набуває для професійної освіти діяльнісний підхід.

На думку академіка І. Зязюна, діяльнісний підхід вносить певні корективи до цілей і завдань освітнього процесу, а також здійснює коригуючу функцію, сприяючи тому, щоб всі суб'єкти освітнього процесу оволоділи цілісною діяльністю ${ }^{8}$.

Ще Дж. Дьюі, основоположник прагматичної педагогіки, зауважував, що діяльність в освітньому процесі повинна мати ключову роль: той, хто навчається, має бути включений у різні види діяльності для здобуття практичного досвіду, саме діяльність має практичну цінність (розвивальну та суспільну) ${ }^{9}$.

Погляди Д. Дьюї, які можуть бути використані у професійній підготовці майбутніх фахівців залізничного транспорту: формування критичного мислення та збагачення власного досвіду кожного студента $\epsilon$ метою освітнього процесу в закладі професійної освіти; орієнтація на індивідуальність кожного, його особистісний розвиток, формування спільних цінностей; засвоєння знань не через трансляцію, а шляхом виконання проблемних завдань із реального життя; інтегровані курси 3 метою формування цілісного уявлення про процеси та явища; викладач відповідає за створення оптимальних умов для розвитку кожного студента, максимально згладжуючи перешкоди для цього; результатом здобутої освіти $\epsilon$ не сукупність розрізнених знань у студентів, а особистість, котра виявляє активність, готова до праці над собою 3 метою підвищення свого професійного рівня, здатна до критичного та гнучкого мислення тощо.

Важливою для нашого дослідження $є$ ідея Д. Дьюї стосовно того, що освіта - це не абсолютизація знання в головах студентів, а підготовка до життя в мінливому світі, в якому постійно виникає

8 Проектування процесу професійного навчання у закладах профтехосвіти : монографія / за ред. Н.Г. Ничкало. Київ - Хмельницький : ХНУ, 2010. С. 13.

9 Дьюї Д. Досвід і освіта / пер. 3 англ. М. Василечко. Львів : Кальварія, 2003. $84 \mathrm{c}$. 
необхідність приймати рішення та вирішувати проблеми ${ }^{10}$. Адже сьогодні існують великі обсяги інформації, що швидко змінюється та постійно оновлюється. Знання, здобуті в закладі професійної освіти, повинні стати підгрунтям для подальшого самовдосконалення та саморозвитку кожної особистості, реалізації власного потенціалу у професійній діяльності, готовності до прийняття важливих виробничих рішень і вміння нести відповідальність за них.

Знання, здібності студента розвиваються, еволюціонують лише в діяльності. Завдання закладу професійної освіти - сприяти розвитку студента, розкриттю його творчого потенціалу, а це можливо лише за умови залучення його до різнопланової діяльності. Особистісні якості теж формуються в тому середовищі, де здобуває освіту майбутній фахівець. Від того, наскільки виконувана студентом діяльність $\epsilon$ особистісно значущою, залежить його розвиток і як особистості, і як фахівця. Від якості виконання різноманітної діяльності залежить формування відповідних умінь, навичок, досвіду, компетенцій, компетентностей.

У психології теорія діяльності почала розвиватися у $\mathrm{XX}$ ст. дослідниками О. Леонтьєвим і С. Рубінштейном, які вважали, що розвиток людини відбувається лише в діяльності та через діяльність ${ }^{11,12}$.

Головна ідея діяльнісного підходу - навчити студентів вчитися, актуалізувати самостійну і творчу діяльність, формувати та розвивати через діяльність мислення, прагнення до пізнання довколишньої дійсності. Саме діяльнісний підхід сприяє розвитку та саморозвитку кожної особистості, іiі здібностей і задатків, розкриттю творчого потенціалу. Психологи стверджують, що розвиток особистості неможливий поза діяльністю. Чим більше виконувана діяльність особистісно значуща для студента, тим результативнішим буде його розвиток і формування особистісних якостей.

На практиці діяльнісний підхід органічно поєднаний з особистісноорієнтованим, тому його деякі науковці називають особистіснодіяльнісним ${ }^{13}$, оскільки в центрі є особистість студента з ії потребами та індивідуальними якостями (задатками, здібностями, особливостями тощо). Діяльнісний підхід у закладах професійної освіти має на меті

10 Ерохин О.К. Джон Дьюи о роли образования. Философия образования. Новосибирск, 2006. № 1.

${ }^{11}$ Леотьев А.Н. Деятельность. Сознание. Лычность. Москва : Смысл; Академия, 2004. 352 c $712 \mathrm{c}$

12 Рубинштейн С.Л. Основы общей психологии. Санкт-Петербург : Питер, 2000.

13 Зимняя И.А. Педагогическая психология : учебник. Москва : Логос, 2000. $384 \mathrm{c}$. 
спрямованість освітнього процесу на особистість кожного студента, на його розвиток, а також врахування в педагогічній взаємодії індивідуальних особливостей кожного студента.

У процесі підготовки майбутніх фахівців залізничного транспорту за умов неперервної освіти діяльнісний підхід відіграє важливу роль. По-перше, студент включений у різнопланову освітньо-пізнавальну діяльність, яка сприяє формуванню умінь i навичок, що стануть підгрунтям для виконання професійної діяльності. По-друге, у процесі виконання діяльності (освітньої, професійної та ін.) відбувається формування та розвиток особистісно значущих якостей: розвивається мислення, формуються лідерські характеристики, відповідальність за якість виконаної діяльності тощо. Діяльнісний підхід, на противагу т. зв. традиційному, перетворює студентів із пасивних спостерігачів у освітній діяльності на активних учасників, котрі $€$ співвідкривачами різноманітних наукових теорій, а також у процесі діяльності студенти набувають досвіду.

Змінюється і роль викладача: за реалізації діяльнісного підходу йому необхідно в освітній діяльності враховувати особистісні характеристики кожного студента, його минулий досвід, створюючи позитивну емоційну атмосферу для подальшого розвитку студента як неповторної особистості.

Діяльнісний підхід у професійній освіті також передбачає, що педагогічна взаємодія між викладачем i студентами набуває особистісного спрямування та потребує врахування індивідуальних характеристик кожного учасника освітнього процесу (якостей, емоцій, досвіду тощо). Цей підхід неможливо реалізовувати за авторитарного стилю спілкування викладача та студентів. Стиль спілкування демократичний, що сприятиме створенню позитивної атмосфери у студентському колективі, налаштуванню на активну пізнавальну діяльність, зняттю психологічної напруги.

Важливим фактором успішної освітньої діяльності студента $\epsilon$ його мотиваційна сфера: наявність позитивної мотивації щодо учіння. Врахування мотивації кожного студента сприятиме досягненню кращих результатів у пізнавальній діяльності студентів. Відмінність в успішності різних студентів частіше $\epsilon$ наслідком відсутності не здібностей, а позитивної мотивації щодо виконання певної діяльності. Тут роль викладача теж посилюється, адже необхідно допомогти кожному студенту сформувати свою ціннісно-мотиваційну сферу, яка сприятиме переведенню освітньої діяльності в категорію особистіснозначущої для кожного конкретного студента.

Проблема формування позитивної мотивації особливо гостро відчутна у студентів I курсу. Змінився соціальний статус - колишній 
учень став студентом. Часто мотивація, якою керувався теперішній студент - колишній учень, зводилася до того, щоб вступити до закладу професійної освіти (коледжу, університету). Ціль досягнута: абітурієнт став студентом. Потрібно сформувати нову мотивацію - вчитися, щоб здобути професію, стати фахівцем, мати можливість продовжити навчання на наступному рівні неперервної професійної освіти тощо.

Наявність позитивної мотивації щодо учіння сприяє тому, що навіть за відсутності яскраво виражених здібностей студент зможе досягти достатніх і високих результатів у майбутній професійній діяльності. Проте наявність здібностей, талантів і задатків без бажання активно працювати не стане гарантією досягнення успіхів студента у процесі освітньої діяльності, а також майбутньої професійної.

Науковці наголошують на існуванні зв'язку між рівнем уявлень про майбутню професійну діяльність та ставлення до неї та позитивною мотивацією щодо учіння ${ }^{14}$.

У процесі здобування професійної освіти відбувається також формування професійної мотивації, пов'язаної з баченням себе в майбутній діяльності. Зростання підвищення професійної мотивації сприяє підвищенню якості освітньої діяльності студента - майбутнього фахівця. Від того, наскільки студент себе бачить у професійній майбутній діяльності, наскільки ця діяльність йому важлива, залежить рівень активності студента в освітній, а потім і у професійній діяльності. Дослідниця І. Зимня вказує на два типи мотивації стосовно професійно-орієнтованого учіння: I тип - мотивація досягнення, II тип - пізнавальна мотивація, базова в освітній діяльності ${ }^{15}$. Для успішного формування мотиваційної сфери студентів викладачеві необхідно володіти інформацією про неї, тобто провести ії дослідження шляхом анкетування, індивідуальних бесід, спостережень. Також викладач повинен володіти адекватними знаннями із психології, а також різними сучасними методиками формування мотивації.

За реалізації діяльнісного підходу у студентів формуються не лише уміння та навички індивідуальної діяльності, а й уміння спілкуватися, працювати в команді. Ці вміння $€$ важливими для подальшого становлення майбутнього фахівця - формуються установки для професійного комунікування.

Діяльнісний підхід на практиці передбачає реалізацію послідовних процесів: добору навчально-методичного матеріалу з урахуванням

14 Сучасний студент у контексті особистісно-діяльнісного підходу: за результатами науково-методичних досліджень : колективна монографія / О.Б. Бігич, М.М. Волошинова, М.С. Глазунов та ін. Київ : КНЛУ, 2014. С. 9.

15 Зимняя И.А. Педагогическая психология : учебник. Москва : Логос, 2000. 384 c. 
індивідуальних особливостей студентів (різнорівневих завдань, використання засобів навчання, які сприятимуть залученню різних органів сприйняття інформації, створення проблемних ситуацій тощо); організації освітньо-пізнавальної діяльності, спрямованої на досягнення мети - розвитку кожного студента шляхом залучення його до активної діяльності, творчості, розв'язання професійних завдань; спілкування між викладачем і студентами, між студентом та іншими студентами сприяє формуванню в майбутніх фахівців навичок професійного спілкування; рефлексії діяльності - аналізу викладачем своєї діяльності та студентів (емоційної атмосфери, досягнення запланованих цілей тощо).

Діяльнісний підхід також передбачає врахування особливостей протікання психічних функцій і процесів у студентів, їх індивідуальних характеристик інтелектуальної діяльності (мислення, уваги, пам'яті, сприйняття, емоційно-вольової сфери тощо). У процесі професійного становлення відбувається розвиток i подальше вдосконалення психічних функцій особистості - логічного, абстрактного мислення, довільної уваги, пам'яті і т. д.

Таким чином, діяльнісний підхід $є$ визначальним для формування майбутніх фахівців залізничного транспорту, їхніх якісних характеристик, формування ключових і професійних компетентностей.

\section{3. Системний підхід у закладах професійної освіти}

Системний підхід початково стосувався лише природничих наук (30-ті pp. XX ст., Л. фон Берталанфі). Проте за кілька десятиліть (60-ті pp. XX ст.) цей підхід активно впроваджується й у практику педагогічних досліджень: виникає потреба описувати та досліджувати педагогічний процес, освітню діяльність у єдності всіх іiі структурних компонентів. 3 філософського погляду системний підхід є способом наукового пізнання дійсності через аналіз взаємодій iї складових елементів. Ключовою дефініцією цього підходу $\epsilon$ «система». У ii значення вкладають різний зміст. Так Л. Берталанфі трактує систему як «поєднання взаємодіючих елементів» ${ }^{16}$. Академік С. Гончаренко дав таке тлумачення «системи»: «комплекс елементів, що перебувають у взаємодії, це різноманіття об'єктів разом із відношеннями між об'єктами та їхніми атрибутами» ${ }^{17}$. Автор наголошує на важливості цілісності педагогічних об'єктів, тому

16 Берталанфи Л. фон. История и статус общей теории систем. Системные исследования. Москва : Наука, 1973.

17 Гончаренко С.У. Український педагогічний словник. Київ : Либідь, 1997. $374 \mathrm{c}$. 
системний підхід покликаний у педагогіці допомогти побачити та дослідити педагогічні елементи в їхній цілісності, а також зв'язки між ними.

Основні принципи системного підходу: цілісність (система як єдине ціле), ієрархічність побудови (підпорядкування хоча б двох рівнів); структуризація (елементи системи й зв'язки між ними); множинність (використання множини різноманітних моделей для опису системи, а також iii окремих елементів); системність (володіння ознаками системи $)^{18}$.

Якщо розглядати професійну підготовку майбутніх фахівців залізничного транспорту як систему, то іiі складниками будуть: цілі (мета) професійної освіти - формування конкурентоспроможного фахівця, зміст професійної освіти (орієнтований на результат, повинен включати як професійну підготовку, так і формування світоглядної позиції, ціннісних орієнтирів, моральних якостей тощо), засоби професійної освіти, форми організації освітньої діяльності, власне освітній процес, суб'єкти й об'єкти освітнього процесу (викладачі, студенти, інший персонал), освітнє середовище, результат освіти.

За допомогою системного підходу можна дослідити й педагогічний процес у закладі професійної освіти. Він підпадатиме під визначення системи, оскільки може бути розглянутий як цілеспрямована діяльність викладачів і студентів, спрямована на розв'язання освітніх проблем i розвиток особистості кожного студента, формування майбутнього фахівця.

Науковець Н. Самборська вказує на те, що, застосовуючи системний підхід до підготовки майбутніх фахівців, необхідно розглядати: систему, яка складається 3 елементів, що водночас $є$ одним цілим; кожна частина $\epsilon$ відображенням цілої системи, проте ціле $\epsilon$ визначальним над множиною елементів; будь-яка система може бути розглянута як сукупність підсистем ${ }^{19}$.

Дослідниця О. Марущак розглядає систему як «комплексний об'єкт, що виник внаслідок інтегрування певних структурних елементів» ${ }^{20}$. Авторка вважає, що на деякому рівні інтеграції відбувається утворення якісно нових характеристик, які не можуть бути виявлені ні як якості

${ }^{18}$ Шабанова Ю.О. Системний підхід у вищій школі. Міністерство освіти й науки України, Національний гірничий університет. Дніпро : НГУ, 2014. 120 с.

19 Самборська Н.M. Соціально-комунікативна компетентність майбутніх медичних працівників у контексті системного та компетентнісного підходів. Проблеми освіти. 2015. № 85. С. 97-101.

20 Марущак О.В. Структура системного підходу до професійної підготовки майбутніх учителів технологій. Сучасні інформаційні технологї̈ та інноваційні методики навчання у підготовці фахівців: методологія, теорія, досвід, проблеми. 2015. Вип. 41. С. 394. 
окремих елементів, ні їх сумарної взаємодії. Тому часто при розгляді певної системи ваги набувають не окремі елементи (склад системи), а іiі структура.

Науковець В. Беспалько наголошує, що саме зв'язки, які виникають у структурі системи, визначають інтегральні показники системи ${ }^{21}$.

Роль системного підходу в пізнанні довколишньої дійсності беззаперечна, адже лише він дозволяє побачити всі грані багатогранної дійсності, проаналізувати подію чи явище під різними кутами. Дослідниця О. Марущак стверджує, що кожному сучасному фахівцеві необхідно володіти системним підходом, знати його основні положення, оскільки кожна особистість живе у багатомірному просторі, на неї діють різноманітні системи, а також будуються стосунки з різними класами об' $є$ ктів $^{22}$.

Науковець Н. Кузьміна, аналізуючи освітній процес у закладах вищої освіти, наголошує: «Педагогічна система $є$ множиною структурних i функціональних компонентів, які підпорядковуються цілям освіти (формування в особистості до самостійного, відповідального та продуктивного розв'язування задач у цій системі) ${ }^{23}$. Початково модель Н. Кузьминої була п'ятикомпонентною, пізніше авторка додала ще два компоненти й отримала модель педагогічної системи, що складається із семи компонентів: організаційного, комунікативного, конструктивного, проективного, гностичного, прогностичного, оціночного.

Розглянемо підготовку майбутніх фахівців залізничного транспорту 3 позиції системного підходу. Системотвірним фактором буде мета підготовки майбутніх фахівців залізничного транспорту конкурентоспроможних на сучасному ринку праці, які володіють професійною компетентністю, готові та здатні до постійного професійного зростання та самовдосконалення. Модель фахівця залізничного транспорту повинна бути побудованою, враховуючи вимоги та запити сучасного суспільства.

Сьогоднішній світ $є$ багатогранним і мінливим. Тому майбутній фахівець залізничного транспорту повинен не лише володіти набором спеціальних знань, а й уміти гнучко використовувати набуті знання,

${ }^{21}$ Беспалько В.П. Системно-методическое обеспечение учебно-воспитательного процесса подготовки специалистов. Москва, 1985. С. 8.

22 Марущак О.В. Структура системного підходу до професійної підготовки майбутніх учителів технологій. Сучасні інформаційні технології та інноваційні методики навчання у підготовиі фахівців: методологія, теорія, досвід, проблеми. 2015. Вип. 41. С. 394.

${ }_{23}$ Кузьмина Н.В. Профессионализм деятельности преподавателя и мастера производственного обучения. Москва : Высшая школа, 1990. С. 13-14. 
сформовані вміння, навички, компетенції та досвід у непередбачуваних професійних обставинах. Сучасному фахівцеві залізничного транспорту мають бути притаманні такі риси, як гнучкість, системність, цілісність мислення, відповідальність за свою діяльність, цілеспрямованість у подоланні труднощів тощо.

Системність мислення досягається шляхом систематизації розрізненої інформації з різноманітних галузей наук, вибудувати систему поняття чи явища, дослідити компоненти та зв'язки між ними. Особистість студента $є$ складовою частиною відразу кількох систем, серед яких і освітня.

Впровадження системного підходу до освітньо-професійної діяльності коледжу 3 метою реалізації сучасної освітньої політики надає можливість бачити освітній процес як систему взаємопов'язаних принципів, форм, методів, технологій, засобів тощо з метою організації та керування процесом відбору та моделювання оптимальних педагогічних умов та освітнього середовища, в якому будуть формуватися майбутні фахівці залізничного транспорту.

У процесі дослідження нами були виявлені й уточнені такі складники системи сучасної підготовки майбутніх фахівців залізничного транспорту, як: оновлення змісту вищої професійної освіти відповідно до вимог часу; впровадження цілісної системи науково обгрунтованих навчальних планів i програм із кожної навчальної дисципліни; ефективна та результативна організація навчальної, пізнавальної, передпрофесійної (допрофесійної) діяльності студентів; єдність ланок вищої освіти (коледж - університет), створення умов для прагнення до професійного вдосконалення, продовження навчання на вищому рівні тощо; сфера їх майбутньої професійної діяльності (єдність теорії та практики, формування досвіду діяльності). Врахування всіх цих складників при організації професійної підготовки майбутніх фахівців залізничного транспорту сприятиме підвищенню якості професійної освіти, формуванню професійної компетентності, визначальних рис характеру тощо.

Професійна підготовка майбутніх фахівців залізничного транспорту повинна бути адекватною вимогам як загальносуспільним, так i індивідуально-особистісним. Вона має відповідати сучасному стану соціально-економічного та науково-технічного розвитку.

Нині вища професійна (допрофесійна) освіта перебуває на етапі вдосконалення й оновлення змістової складової частини, оскільки повинна готувати фахівців для майбутнього, а не для минулого. Потребують перегляду мета, завдання, функції, способи реалізації, управління якістю, планування результатів тощо. 
Будемо розглядати професійну підготовку майбутніх фахівців залізничного транспорту як систему, оскільки для нас є важливою як взаємодія окремих компонентів між собою, так і взаємодія системи із зовнішнім середовищем. Кожен компонент системи може бути розглянутий як підсистема зі своїм компонентним складом. Зазначимо, що професійна підготовка майбутніх фахівців залізничного транспорту може бути розглянута як складна багаторівнева система, котру можна досліджувати як на макро-, так і на мікрорівнях. У цій системі також може бути досліджено функціонування об'єктів, які перебувають між собою на різних рівнях ієрархії (нижчий рівень - вищий рівень); дослідження «підсистем у системі» дозволяє здійснювати вдосконалення та покращення зв'язків між компонентами освітнього процесу, що діють як по вертикалі, так і по горизонталі.

Аби побудована система була ефективною, необхідно, щоб іiі підгрунтям були на наукові принципи, чіткість логічної структури (зв'язки між рівнями), вона могла бути втіленою в життя. У цій системі має бути чітко зазначено функціональні обов'язки керівників / підлеглих, викладачів / прописано права й обов'язки студентів та ін.

Розглянемо модель професійної підготовки майбутніх фахівців залізничного транспорту з позиції системного підходу. Професійну освіту будемо розглядати як єдність компонентів: змістового; освітнього; особистісного; управлінського; діяльнісного; результативного; стратегічного.

1. Змістовий компонент - включає в себе мету, завдання, зміст вищої професійної освіти; дає відповіді на запитання: «кого вчити?», «як вчити?». Сюди входять навчальні плани, програми, нормативноправова база тощо.

2. Освітній компонент - включає в себе форми, методи, засоби, технології організації освітнього процесу, а також викладацький склад навчального закладу.

3. Особистісний компонент - розвиток кожної особисті, котра $є$ суб'єктом професійної підготовки, розкриття творчого потенціалу, формування визначальних рис характеру.

4. Результативний компонент - $\epsilon$ кінцевим результатом освітнього процесу, відповідністю набутих компетентностей вимогам ринку праці, суспільства загалом і кожної особистості зокрема.

5. Стратегічний компонент передбачає наявність у закладі освіти, а також у державі плану стратегічного розвитку галузі хоча б на десять років. Він дає можливість спрогнозувати та передбачити потреби в фахівцях певної галузі, а також вимоги до них.

6. Діяльнісний компонент - передбачає включення всіх суб'єктів освітнього процесу до активної діяльності. 
7. Управлінський компонент - професійна освіта не $є$ чимось спонтанним і хаотичним, вона підпорядкована керівникам на різних ієрархічних рівнях, а також нормативно-правовій базі Міністерства освіти і науки України, Департаментам в галузі вищої та професійної освіти.

Таким чином, професійна освіта має системну структуру, компоненти якої пов'язані між собою різнорівневими зв'язками. Ці зв'язки мають місце на мікрорівнях (у межах одного закладу освіти), а також на макрорівнях (у межах країни, в світовій системі тощо).

3 психологічного погляду зазначимо, що перед студентом як суб'єктом професійної підготовки постає низка особистіснопсихологічних завдань, які він повинен вирішити самостійно: обгрунтування професійної важливості кожної навчальної дисципліни від загальноосвітньої до спеціальної; усвідомлення потреби усестороннього дослідження освітнього матеріалу з усіх дисциплін; сприйняття кожної навчальної дисципліни як важливої складової частини професійної підготовки за умов неперервності освіти; формування професійного ідеалу, прагнення його осягнути як кінцевого результату професійної підготовки; формування особистісної моделі готовності до професійної діяльності; вміння узагальнювати наявні знання та структурувати їх щодо майбутньої професійної діяльності, усвідомлення мінливості знання та прагнення до постійного вдосконалення та підвищення рівня професійної діяльності у світлі мінливості вимог до професійних обов'язків; подолання всіх соціальних бар'єрів, що стоять на шляху професійного зростання; вміння систематизувати й узагальнювати розрізнену інформацію, окремі факти про навколишню дійсність, бачити в кожній навчальній дисципліні вектор на професійну діяльність; формування системи ціннісно-мотиваційних орієнтирів, розробка індивідуальноособистісного плану розвитку (саморозвитку), побудова власної стратегії навчання та життя, вміння здійснювати самоаналіз освітньої та професійної діяльності, адекватно співвідносити характеристики діяльності (якість, кількість, час тощо); аналіз особистісного включення в різноманітні соціально значущі системи, правильна розстановка пріоритетів (центральною системою у період навчання в закладі вищої / професійної освіти має бути професійна підготовка) тощо.

\section{ВИСНОВКИ}

Професійна підготовка майбутніх фахівців залізничного транспорту за умов неперервної освіти нині перебуває на етапі оновлення та вдосконалення, перегляду змісту навчальних програм i планів відповідно до сучасних єдиних вимог - професійної компетентності. 
Особистість із ऑiі індивідуальними особливостями, здібностями та задатками є центральною складовою частиною системи професійної підготовки майбутніх фахівців залізничного транспорту. Тому процес професійного становлення майбутнього фахівця має базуватися на розвитку кожної особистості, а також задовольняти потреби як конкретної особисті, так і суспільства загалом.

Нині професійна підготовка майбутніх фахівців залізничного транспорту потребує перегляду концептуальних засад, адже мінливість інформаційного потоку та стрімкий науково-технічний прогрес, а також євроінтеграційні процеси як всередині України, так i загальноєвропейські, зумовлюють постійно зростаючі вимоги до фахівців залізничного транспорту як складової частини системи транспортної інфраструктури.

Нашим дослідженням продемонстровано, що важливого значення у процесі професійної підготовки майбутніх фахівців залізничного транспорту мають методологічні підходи, зосереджені на особистості студента, його розвитку, розкритті творчого потенціалу, формуванні якісних професійно-значущих рис характеру. До таких підходів ми віднесли: особистісно-орієнтований, діяльнісний і системний.

На нашу думку, синтез цих підходів максимально сприяє досягненню мети професійної освіти - становлення кваліфікованого фахівця нової генерації, готового та здатного до професійного зростання та саморозвитку як у процесі здобуття освіти на різних рівнях неперервної освіти, так і після закінчення навчання у закладах вищої освіти у форматі підвищення кваліфікації.

\section{АНОТАЦІЯ}

Дослідження присвячене висвітленню проблем професійної підготовки майбутніх фахівців залізничного транспорту в системі неперервної освіти. Проаналізовано підготовку майбутніх фахівців залізничного транспорту 3 позицій особистісно-орієнтованого, діяльнісного та системного підходів. Вибір цих підходів зумовлено наявністю в центрі кожного $з$ них особистості з ії індивідуальними особливостями, задатками та здібностями. Розкрито специфіку кожного з виокремлених методологічних підходів. Досліджено їх значення для розвитку особистості та вплив на формування майбутнього фахівця. Виокремлено компоненти моделі професійної підготовки майбутніх фахівців залізничного транспорту з позиції системного підходу: змістовий, освітній, особистісний, управлінський, діяльнісний, результативний, стратегічний. Реалізація цих підходів у практичній діяльності, спрямованій на професійну підготовку майбутніх фахівців залізничного транспорту, сприяє підвищенню якості освіти в умовах 
неперервної освіти, єдності теоретичного та практичного складників, формуванню професійної компетентності, прагнення до самовдосконалення та підвищення професійного рівня.

\section{ЛIТЕРАТУРА}

1. Abraham H. Maslow. Motivation and Personality. New York : Harper \& Row, 1970; Санкт-Петербург : Евразия, 1999.

2. Роджерс К. Становление личности: взгляд на психотерапию. URL: http://psylib.org.ua/books/roger01/index.htm.

3. Авдеева Н. Ключевые компетенции - новая парадигма результата образования. Педагогика. 2003. № 5. С. 34-39.

4. Профтехосвіта України: XX століття / за ред. Н.Г. Ничкало. Київ : АртЕк, 2004. С. 523.

5. Горбатюк О.В. Особистісно орієнтований підхід до навчання в ВНЗ у сучасних умовах. Збірник наукових прачь Кам'янецьПодільського начіонального університету ім. Івана Огієнка. Серія: Педагогіка. 2014. Вип. 20. С. 252-253.

6. Шамова Т.И. Управление образовательным процессом в адаптивной школе. Москва : Центр «Педагогический поиск», $2001.384 \mathrm{c}$.

7. Якиманская И.С. Технология личностно-ориентированного обучения в современной школе. Москва : Сентябрь, 2000. 176 с.

8. Проектування процесу професійного навчання у закладах профтехосвіти : монографія / за ред. Н.Г. Ничкало. Київ Хмельницький : ХНУ, 2010.335 с.

9. Дьюї Д. Досвід і освіта / пер. 3 англ. М. Василечко. Львів : Кальварія, 2003. 84 с.

10. Ерохин О.К. Джон Дьюи о роли образования. Философия образования. Новосибирск, 2006. № 1.

11. Леотьев А.Н. Деятельность. Сознание. Лычность. Москва : Смысл; Академия, 2004. 352 с.

12. Рубинштейн С.Л. Основы общей психологии. Санкт-Петербург : Питер, 2000. 712 с.

13. Зимняя И.А. Педагогическая психология : учебник. Москва : Логос, 2000. 384 с.

14. Сучасний студент у контексті особистісно-діяльнісного підходу: за результатами науково-методичних досліджень : колективна монографія / О.Б. Бігич, М.М. Волошинова, М.С. Глазунов та ін. Київ : КНЛУ, 2014. 148 c.

15. Берталанфи Л. фон. История и статус общей теории систем. Системные исследования. Москва : Наука, 1973. 
16. Гончаренко С.У. Український педагогічний словник. Київ : Либідь, 1997. 374 с.

17. Шабанова Ю.О. Системний підхід у вищій школі. Міністерство освіти й науки України, Національний гірничий університет. Дніпро : НГУ, 2014. $120 \mathrm{c}$.

18. Самборська Н.M. Соціально-комунікативна компетентність майбутніх медичних працівників у контексті системного та компетентнісного підходів. Проблеми освіти. 2015. № 85. С. 97-101.

19. Марущак О.В. Структура системного підходу до професійної підготовки майбутніх учителів технологій. Сучасні інформаційні технології та інноваційні методики навчання у підготовиі фахівиів: методологія, теорія, досвід, проблеми. 2015. Вип. 41. С. 394-399.

20. Беспалько В.П. Системно-методическое обеспечение учебновоспитательного процесса подготовки специалистов. Москва, 1985. $398 \mathrm{c}$.

21. Кузьмина Н.В. Профессионализм деятельности преподавателя и мастера производственного обучения. Москва : Высшая школа, 1990.

Information about the author:

Malaniuk N. M.,

Ph.D. in Pedagogic Sciences,

Lecturer of Mathematics

Kyiv College of Transport Infrastructure 16, Yaroslava Khomova str., Kyiv, Ukraine 